\title{
Menguji Kepastian Hukum Penyelesaian Perselisihan Di Bidang Hilir Minyak dan Gas Bumi Oleh Badan Pengatur Dara Salsabila \\ Universitas Padjadjaran, Bandung
}

\author{
INFORMASI NASKAH \\ Diterima: 17 Juli 2021 \\ Direvisi: 18 Juli 2021 \\ Disetujui: 30 September \\ 2021
}

Terbit: 30 September 2021

Email korespondensi:

darajelitasalsabila@

gmail.com

Laman daring:

https://doi.org/10.37525/

$\mathrm{sp} / 2021-2 / 287$

\begin{abstract}
ABSTRAK
Badan Pengatur memiliki wewenang dalam penyelesaian perselisihan sebagaimana dinyatakan pada peraturan perundangundangan yang berlaku. Optimalisasi peran Badan Pengatur penting dilakukan untuk menjamin kontinuitas penyelenggaraan berusaha di bidang hilir minyak dan gas bumi yang baik. Selain itu proses ini juga bertujuan untuk menghindari perselisihan antar Badan Usaha untuk masuk ke ranah Pengadilan yang membutuhkan biaya besar, proses yang lama dan bersifat winlose solution. Dengan adanya pendekatan alternatif penyelesaian sengketa diharapkan perselisihan dapat terselesaikan dengan cara kekeluargaan dan menjamin kerahasiaan badan usaha serta mengedepankan win-win solution. Akan tetapi permasalahannya adalah Badan Pengatur belum memiliki peraturan perundangundangan yang mengatur secara konkret proses beracara dalam penyelesaian perselisihan ini, sehingga berimplikasi terhadap ketiadaan kepastian hukum dan preseden yang baik bagi Badan Usaha atau para pihak.

Kata kunci: Arbitrase; Badan Pengatur; Badan Usaha; Mediasi; dan Perselisihan
\end{abstract}

\section{PENDAHULUAN}

Sebagai bentuk konsekuensi logis adanya hubungan hukum antar badan hukum, berpotensi terjadinya persengketaan atau perselisihan mengenai hak dan kewajiban para pihak termasuk pada bidang hilir minyak dan gas bumi. Sengketa atau yang dalam terminasi Undang-Undang Nomor 22 Tahun 2001 tentang Minyak dan Gas Bumi (UU Migas 2001) adalah perselisihan mengandung dimensi privat atau keperdataan sehingga perselisihan yang terjadi diuji berdasarkan perjanjian yang telah disepakati oleh para pihak. Selain itu perselisihan pada bidang hilir minyak dan gas bumi juga memiliki dimensi publik seperti dalam Putusan Mahkamah Agung 270/K/ Pid.Sus/2015 tanggal 7 Desember 2015 berkaitan dengan Izin Usaha Pengangkutan oleh Ditjen Migas yang apabila ditarik secara komprehensif, akar permasalahannya adalah berdasarkan pola kontrak kerjasama. Kedua ranah hukum ini secara konvergen saling mempengaruhi satu sama lain.

UU Migas 2001 selain mengatur mengenai kegiatan hulu dan hilir minyak dan gas bumi juga melegitimasi penetapan dua badan yang tugas dan fungsinya adalah pengurusan dan pengaturan 
serta pengawasan kegiatan dan/atau usaha minyak dan gas bumi yakni Badan Pelaksana dan Badan Pengatur. Untuk selanjutnya penulis hanya akan mengkonstruksikan Badan Pengatur dalam penulisan ini yang diartikan sebagai suatu badan yang dibentuk untuk melakukan pengaturan dan pengawasan terhadap penyediaan dan pendistribusian Bahan Bakar Minyak (BBM) dan Gas Bumi pada kegiatan Usaha Hilir. Dengan demikian secara kompetensi pengorganisasian urusan dibidang minyak dan gas bumi telah diklasifikasikan dengan sangat baik. Merujuk pada Peraturan Pemerintah Nomor 36 Tahun 2004 tentang Kegiatan Hilir Minyak dan Gas Bumi Jo. Peraturan Pemerintah Nomor 30 Tahun 2009 tentang Perubahan Atas Peraturan Pemerintah Nomor 36 Tahun 2004 tentang Kegiatan Usaha Hilir Minyak dan Gas Bumi menyatakan bahwa Badan Pengatur memiliki kewenangan melakukan penyelesaian perselisihan yang timbul berkaitan dengan kegiatan usaha Niaga BBM sebagaimana terdapat pada Pasal 8 ayat (1) huruf f; menyelesaikan perselisihan yang timbul terhadap pemegang Hak Khusus pengangkutan Gas Bumi melalui pipa dan/atau yang berkaitan dengan pelaksanaan pengangkutan Gas Bumi melalui pipa sebagaimana terdapat pada Pasal 9 ayat (1) huruf g PP a quo. Dengan demikian menjadi jelas bahwa Badan Pengatur memiliki kewenangan menyelesaikan perselisihan (yang timbul berdasarkan konsep business to business keperdataan antar badan usaha).

Menjadi permasalahan kemudian adalah mengenai legal framework atas konsep mekanisme penyelesaian perselisihan yang dilakukan oleh Badan Pengatur ini, sebab secara bentuk dan isi mengacu pada penyelesaian sengketa di luar pengadilan (non-litigasi), akan tetapi jika berpedoman pada Pasal 8 ayat (2) PP a quo menyatakan, dalam hal penyelesaian perselisihan yang dilakukan oleh Badan Pengatur tidak dapat diterima oleh Badan Usaha atau para pihak, Badan Usaha atau para pihak dapat mengajukan keberatan melalui Pengadilan Negeri Jakarta Pusat; bersamaan dengan itu pada Pasal 9 ayat (2) menyatakan, dalam hal penyelesaian perselisihan yang dilakukan oleh Badan Pengatur tidak dapat diterima oleh Badan Usaha atau para pihak, Badan Usaha atau para pihak dapat mengajukan keberatan melalui Pengadilan Negeri Jakarta Pusat. Adapun pertimbangan Pengadilan Jakarta Pusat yang memiliki kewenangan pemeriksaan dan mengadili adalah karena berkaitan dengan letak Badan Pengatur yang saat ini hanya ada di Jakarta, sehingga dari konstruksi ini mengacu pada kompetensi relatif daripada Pengadilan Jakarta Pusat.

Sampai dengan penelitian ini dilakukan, belum terdapat peraturan perundang-undangan dan/ atau peraturan kebijakan yang dibuat dan ditetapkan oleh Badan Pengatur sehubungan dengan proses beracara formil penyelesaian perselisihan yang dilakukan oleh Badan Pengatur. Penting menjadi fokus Badan Pengatur mengenai ini, sebab dengan adanya rigiditas penyelesaian perselisihan yang nantinya ditetapkan oleh Badan Pengatur maka akan berkorelasi terhadap kepastian hukum bagi badan usaha yang berselisih dan menyelesaikannya tanpa harus terlebih dahulu masuk ke Pengadilan, sehingga peran Badan Pengatur sangat sentralistik di sini sebagai penengah atas Badan Usaha. Bahkan sejak tahun diundangkannya PP 36 Tahun 2004, setelah tujuh belas tahun belum terhadap aturan mengenai proses beracaranya. Mengingat bahwa peran Badan Pengatur sangat besar, harapannya setiap penyelesaian perselisihan dapat menjadi preseden yang baik dalam penyelesaian perselisihan badan usaha lainnya melalui upaya optimalisasi penyelesaian perselisihan diluar pengadilan sehingga menempatkan pengadilan sebagai Ultimum remedium sebagaimana hakikatnya.

Berdasarkan uraian diatas maka dikemukakan beberapa rumusan masalah sebagai berikut:

1. Bagaimana kedudukan hukum Badan Pengatur saat melakukan penyelesaian perselisihan antar Badan Usaha atau para pihak di bidang hilir minyak dan gas bumi? 
2. Bagaimana kekuatan hukum ketetapan Badan Pengatur sebagai hasil penyelesaian perselisihan Badan Usaha atau para pihak dengan adanya upaya keberatan pada Pengadilan Negeri Jakarta Pusat?

Adapun tujuan dari penelitian ini ditinjau dari perspektif teoritis dan praktis. Secara teoritis bertujuan mengkonstruksikan secara yuridis mengenai kewenangan Badan Pengatur dalam penyelesaian sengketa minyak dan gas bumi di Indonesia, sedangkan secara praktis ditujukan sebagai bahan kajian dan evaluasi bersama mengenai mekanisme penyelesaian perselisihan yang dilakukan oleh Badan Pengatur. Manfaat penelitian ini adalah dapat menjadi rekomendasi bagi Badan Pengatur Cq. Kepala Badan Pengatur mengenai urgensi adanya peratuan kebijakan untuk melegitimasi proses beracara di Badan Pengatur sehubungan dengan penyelesaian perselisihan tersebut

\section{TINJAUAN PUSTAKA}

Secara konsep, penyelesaian perselisihan yang dilakukan oleh Badan Pengatur sebagaimana ketentuan tersebut mengacu pada konstruksi penyelesaian perselisihan non litigasi (di luar pengadilan) dan bersifat alternatif, sehingga konsep yang ditelaah dalam penelitian ini adalah mengenai konsep Alternatif Dispute Resolution (ADR). ADR menurut Robert H Mnookin, refers to a set of practices and techniques aimed at permitting the resolution of legal disputes outside the courts, it is normally thought to encompass mediation, arbitration and a variety of hybrid processes by which a netral facilitates the resolution of legal disputes without formal adjudication. ${ }^{1}$ Prinsip ini kemudian dituangkan dalam Undang-Undang Nomor 30 Tahun 1999 tentang Arbitrase dan Alternatif Penyelesaian Sengketa (UU APS) yang secara eksplisit menyatakan bahwa arbitrase adalah cara penyelesaian suatu sengketa perdata di luar peradilan umum yang didasarkan pada perjanjian arbitrase yang dibuat secara tertulis oleh para pihak yang bersengketa; sedangkan Alternatif Penyelesaian Sengketa adalah lembaga penyelesaian sengketa atau beda pendapat melalui prosedur yang disepakati para pihak yakni penyelesaian di luar pengadilan dengan cara konsultasi, negosiasi, mediasi, konsiliasi atau penilaian ahli.

Secara general ADR yang diterapkan oleh Badan Pengatur merupakan kombinasi antara ADR inside the court sebagaimana diterapkan pada sistem hukum Amerika Serikat dan ADR outside the court sebagaimana Korean Commercial Arbitration Board dll terapkan. Interpretasi ini dilakukan sebab pada perselisihan yang diselesaikan oleh Badan Pengatur berpeluang untuk diajukan keberatan, dengan demikian ketetapan yang dikeluarkan oleh Badan Pengatur tidak bersifat final and binding. Adapun pihak-pihak yang berselisih berdasarkan norma ini adalah Badan Usaha yang diartikan sebagai perusahaan berbentuk badan hukum yang menjalankan jenis usaha bersifat tetap, terus menerus dan didirikan sesuai dengan peraturan perundang-undangan yang berlaku serta bekerja dan berkedudukan dalam wilayah Negara Kesatuan Republik Indonesia (NKRI) (Pasal 1 angka 17 UU Migas). Terhadap badan usaha yang didirikan dan berbadan hukum di luar NKRI yang melakukan kegiatan di wilayah NKRI dan wajib mematuhi peraturan perundang-undangan yang berlaku di Republik Indonesia disebut sebagai Badan Usaha Tetap dan merupakan subyek hukum di Indonesia juga (Pasal 1 angka 18 UU Migas).

1 Robert Mnookin, Alternative Dispute Resolution, Harvard Law School John M Olin Center for Law, Economics and Business Discussion Papaer Series 232, hlm 1. 


\section{METODE PENELITIAN}

Metode penelitian dilakukan dengan jenis penelitian kualitatif berdasarkan data-data sekunder seperi Peraturan perundang-undangan, buku, artikel jurnal dll, dan dengan metode pendekatan yuridis normatif yakni mengkaji realitas hukum berpedoman pada peraturan perundang-undangan. Spesifikasi penelitian ini adalah deksriptif-eksploratif.

\section{HASIL PENELITIAN DAN PEMBAHASAN}

\section{A. Kedudukan Diametral Badan Pengatur dalam Penyelesaian Perselisihan}

Pada dasarnya kewenangan Badan Pengatur berada pada rezim hukum publik dengan lex specialis sebagai Badan dan/atau Pejabat Tata Usaha Negara, sehingga memiliki otorisasi tersediri dalam berbuat sesuatu, tidak berbuat sesuatu dan/atau memberikan sesuatu dalam konstruksi hubungan hukum bersegi satu (eenzijdige rechtsbetrekkingen). ${ }^{2}$ Otorisasi ini diatur dalam Pasal 1 angka 2 Undang-Undang Nomor 5 Tahun 1986 tentang Peradilan Tata Usaha Negara (UU Peratun) yang mengartikan Badan atau Pejabat tata Usaha Negara adalah Badan atau Pejabat yang melaksanakan urusan pemerintahan berdasarkan peraturan perundangundangan yang berlaku. Sejalan dengan itu dalam Pasal 1 angka 3 Undang-Undang Nomor 30 Tahun 2014 tentang Administrasi Pemerintahan (UU AP) menyatakan bahwa Badan dan/ atau Pejabat Pemerintahan adalah unsur yang melaksanakan Fungsi Pemerintahan, baik di lingkungan pemerintah maupun penyelenggara negara lainnya. Maka dikonklusikan badan publik yang disandang oleh Badan Pengatur mengacu pada tugas, fungsi dan kewenangannya.

Pasal 8 PP No. 36 Tahun 2004 menyatakan bahwa Badan Pengatur melakukan berwenang menetapkan kewajiban Badan Usaha yang akan atau telah mempunyai Izin Usaha dari Menteri untuk menjamin ketersediaan dan distribusi BBM, menyediakan dan mendistribusikan BBM didaerah yang mekanisme pasarnya belum berjalan dan Daerah Terpencil, menetapkan alokasi cadangan BBM dari masing-masing Badan Usaha dll. Terhadap kewenangan ini dilakukan secara sepihak oleh Badan Pengatur tanpa harus adanya approval dari Badan Usaha sebab merupakan lingkup tindakan segi satu. Selain itu hubungan yang tercipta secara implisit terdapat hubungan hirarkis diantara Badan Pengatur dengan Badan Usaha.

Akan tetapi merujuk pada huruf f-nya, maka hubungan hukum antara Badan Usaha dengan Badan Usaha lainnya bersama Badan Pengatur berada pada hubungan hirarkis yang setara. Hal ini disebabkan penyelesaian perselisihan yang dikemukakan oleh Badan Pengatur berupa mediasi, dan arbitrase. Tujuannya adalah agar perselisihan dapat diselesaikan berdasarkan mekanisme di atas sebab inti permasalahannya adalah pada hak dan kewajiban.

Dalam PP No. 36 Tahun 2004 Jo. PP No. 30 Tahun 2009 tidak menyatakan secara eksplisit konsep hasil perselisihan yang dilakukan oleh Badan Pengatur baik itu secara materil maupun formil. Dengan demikian antar satu ketetapan yang telah diputuskan oleh Badan Pengatur dapat saja menjadi preseden bagi kasus serupa atau dapat menekankan adanya fleksibelitas dalam upaya dan proses penyelesaian perselisihan dengan cara pandang kasus demi kasus. Fleksibilitas ini akan berpengaruh terhadap kepentingan hukum dan kepastian hukum bagi Badan Usaha atau para pihak.

2 Soeroso, Pengantar Ilmu Hukum, Jakarta: Sinar Grafika, 2006 hlm 269. 
Pada Rapat Dengar Pendapat yang dilakukan tanggal 13 Februari 2020 antara Badan Pengatur dengan Dewan Perwakilan Rakyat Republik Indonesia salah satunya membahas peran dalam melakukan penyelesaian perselisihan (mediasi) di bidang BBM dan Gas Bumi melalui pipa yang bertumpu pada tiga kepentingan yakni pemerintah, pelaku usaha dan masyarakat. ${ }^{3}$ Dengan demikian yang diinterpretasikan oleh Badan Pengatur mengenai penyelesaian perselisihan hanya pada mekanisme mediasi. Mediasi merupakan proses penyelesaian sengketa para pihak yang dilakukan dengan bantuan mediator atau pihak ketiga yang bersifat netral dan tidak memihak dan berugas sebagai fasilitator, sedangkan keputusan untuk mencapai kesepakatan akan tetap diserahkan kepada para pihak dan tidak oleh mediator. ${ }^{4}$ Maka peran Badan Pengatur dalam penyelesaian beberapa perselisihan bertindak sebagai mediator. Dalam pandangan Jacqueline M dan Nolan Haley terdapat beberapa tahapannya terdiri dari screening, mediator describes process and role of mediator dan mediator assists parties in drafting agreement, ${ }^{5}$ sehingga penyelesaian perselisihan dilakukan berdasar atas kesepakatan para pihak dan bagi mediator berperan sebagai penyelenggara pertemuan; pemimpin proses diskusi yang netral; pemelihara aturan perundingan agar berjalan secara beradab; pengendali emosi para pihak dan pendorong pihak yang kurang mampu untuk mengemukakan pendapatnya. ${ }^{6}$

Dalam menjalankan perannya sebagai mediator maka Badan Pengatur berada pada posisi hirarkis yang seimbang dengan Badan Usaha atau para pihak, dengan demikian kedudukan diametral Badan Pengatur terlihat pada konstruksi sebagaimana disebutkan diatas. Sejalan dengan pengertian dalam Collins English Dictionary and Thesurus yang menyatakan, mediasi adalah kegiatan untuk menjembatani antara dua pihak yang berselisih untuk menghasilkan suatu agreement atau kesepakatan. ${ }^{7}$

\section{B. Kekuatan Hukum Ketetapan Badan Pengatur dalam Proses Penyelesaian Perselisihan antar Badan Usaha}

Bentuk penyelesaian perselisihan dilakukan dengan mediasi maka keputusan yang dihasilkan adalah berdasarkan kesepakatan para pihak. Berbeda konteksnya dengan arbitrase yang mana seorang atau lebih arbiter memiliki kuasa penuh dan aktif dalam menyelesaikan perselisihan Badan Usaha. Adapun hasil dari proses arbitrase ini adalah berupa Putusan Arbitrase. Putusan Arbitrase adalah putusan yang mengikat para pihak dan dengan melalui tata cara (prosedur) sederhana saja ataupun langsung dapat dilaksanakan sebagaimana terdapat pada ketentuan Penjelasan UU APS. Akan tetapi dalam tataran praksisnya di Indonesia, eksekusi terhadap putusan arbitrase masih terkendala padahal dalam UU APS sudah melegitimasi final dan binding atau mengikatnya putusan ini. selain itu Indonesia pun sudah meratifikasi New York Convention Tahun 1958 melalui Keputusan Presiden Nomor 34 Tahun 1981 tentang Mengesahkan Convention on the Recognition and Enforcement of Foreign Arbital Awards yang telah di Tandatangani di New York pada tanggal 10 Juni 1958 dan Telah Mulai Berlaku pada Tanggal 7 Juni 1959 yang mewajibkan setiap putusan arbitrase yang ditetapkan untuk dijalankan.

\footnotetext{
3 Bagja Rahmatullah, Rapat Dengar Pendapat dengan BPH Migas, Komisi VII DPR RI Dukung Kinerja dan Penguatan Peran BPH Migas, diakses melalui https://www.bphmigas.go.id/berita-bbm/rapat-dengar-pendapatdengan-bph-migas-komisi-vii-dpr-ri-dukung-kinerja-dan-penguatan-peran-bph-migas/ pada 31 Mei 2021.

4 I Made, Alternative Penyelesaian Sengketa (ADR), Indonesia Business Law Center (IBLC), 2007 hlm 107.

5 Suyud Margono, ADR, Alternative Dispute Resolution and Arbitration, Bogor: Ghalia Indonesia 2004 hlm 54.

6 Ibid hlm 52.

7 Lorna Gilmour, Penny Hand dan Cormac McKeown, Collins English Dictionary and Thesaurus, Third Edition Great Britain:Herper Colins Publishers, 2007 hlm 510.
} 
Antara agreement yang dihasilkan dari proses mediasi yang dilakukan oleh Badan Pengatur memiliki validitas implementasi yang lebih rendah dibandingkan dengan Arbitrase. Sebab dalam UU APS dinyatakan bahwa, Pasal 59 UU AP, dalam waktu paling lama 30 (tiga puluh) hari terhitung sejak tanggal putusan diucapkan, lembar asli atau salinan otentik putusan arbitrase diserahkan dan didaftarkan oleh arbiter atau kuasanya kepada Panitera Pengadilan Negeri. Apabila tidak dilakukan proses ini maka berimplikasi bahwa putusan arbitrase tidak dapat dilaksanakan, sehingga legitimasi executoir putusan arbitrase tetap berada pada majelis hakim pengadilan negeri setempat. Berbeda dengan agreement mediasi yang hanya berupa kesepakatan untuk berdamai dan menyelesaikan kewajiban dan/atau kewajiban yang disesuaikan oleh para pihak saja.

\section{KESIMPULAN}

Hingga kini peraturan perundang-undangan mengenai proses beracara secara formil terhadap penyelesaian perselisihan di bidang hilir minyak dan gas bumi belum ada. Maka dari itu adanya urgenitas dalam penetapan peraturan a quo agar dalam menyelesaikan perselisihan Badan Pengatur memiliki panduan yang rigid, selain itu juga bertujuan untuk menjamin kepastian hukum Badan Usaha. Disisi lain materi muatan terkait kedudukan dan hubungan hukum Badan Pengatur dalam penyelesaian sengketa harus dimasukkan sehingga menjadi jelas peran daripada masing-masing pihak.

\section{DAFTAR PUSTAKA}

Bagja Rahmatullah, Rapat Dengar Pendapat dengan BPH Migas, Komisi VII DPR RI Dukung Kinerja dan Penguatan Peran BPH Migas, diakses melalui https://www.bphmigas. go.id/berita-bbm/rapat-dengar-pendapat-dengan-bph-migas-komisi-vii-dpr-ri-dukung-kinerjadan-penguatan-peran-bph-migas/

I Made, Alternative Penyelesaian Sengketa (ADR), Indonesia Business Law Center (IBLC), 2007.

Lorna Gilmour, Penny Hand dan Cormac McKeown, Collins English Dictionary and Thesaurus, Third Edition Great Britain:Herper Colins Publishers, 2007.

Robert Mnookin, Alternative Dispute Resolution, Harvard Law School John M Olin Center for Law, Economics and Business Discussion Papaer Series 232.

Soeroso, Pengantar Ilmu Hukum, Jakarta: Sinar Grafika, 2006.

Suyud Margono, ADR, Alternative Dispute Resolution and Arbitration, Bogor: Ghalia Indonesia 2004. 